\title{
A Pragmatist Conception of Certainty
}

Wittgenstein and Santayana

\section{Guy Bennett-Hunter}

\section{(2) OpenEdition}

\section{Journals}

Electronic version

URL: http://journals.openedition.org/ejpap/728

DOI: $10.4000 /$ ejpap.728

ISSN: 2036-4091

Publisher

Associazione Pragma

\section{Electronic reference}

Guy Bennett-Hunter, «A Pragmatist Conception of Certainty », European Journal of Pragmatism and American Philosophy [Online], IV-2 | 2012, Online since 24 December 2012, connection on 01 May 2019. URL : http://journals.openedition.org/ejpap/728; DOI : 10.4000/ejpap.728

This text was automatically generated on 1 May 2019.

\section{(c) $($ ) $\odot$ (8Y NO}

Author retains copyright and grants the European Journal of Pragmatism and American Philosophy right of first publication with the work simultaneously licensed under a Creative Commons AttributionNonCommercial-NoDerivatives 4.0 International License. 


\title{
A Pragmatist Conception of Certainty
}

Wittgenstein and Santayana

\author{
Guy Bennett-Hunter
}

\section{AUTHOR'S NOTE}

I would like to thank the Institute for Advanced Studies in the Humanities at the University of Edinburgh for awarding me the Postdoctoral Research Fellowship that made possible the research for, and writing of, this paper between January and August 2012.

Goodman (2002) has perceptively drawn attention to some ways in which Wittgenstein's thought can be regarded as 'pragmatist.' Using James's Pragmatism as his main point of reference, he identifies a number of pragmatist themes in Wittgenstein's (1969) On Certainty, among which we also find Wittgenstein's (1969: § 422) direct statement, "I am trying to say something that sounds like pragmatism." Notably, Goodman (2002: 21-3) identifies the Wittgensteinian notion of hinge propositions as being among these pragmatist themes. ${ }^{1}$ In the first part of this paper, I want to set out briefly the conception of hinge propositions as articulated in On Certainty and then draw on Pritchard's (2011, 2012) recent reading of their nature and significance to articulate the Wittgensteinian concept of certainty implied by that reading.

2 Wittgenstein develops the notion of hinge propositions from the observation that, whenever we doubt something, there must always be something which is not doubted, taken for granted, as the background against which the doubt arises. If we have a doubt about whether something is the case, we may engage in the practice of checking or testing the object of the doubt. As Wittgenstein (1969: § 163) illustrates the way in which this checking process works: 
We check the story of Napoleon, but not whether all the reports about him are based on sense-deception, forgery and the like. For whenever we test anything, we are already presupposing something that is not tested.

3 Later on, he makes the same point by pointing out that when I conduct an experiment to test the truth of some proposition of which I am doubtful, I do not doubt the existence of the apparatus before my eyes (Wittgenstein 1969: $\S \S 163,337$ ). The practice of testing certain propositions, the truth of which is not beyond doubt, presupposes that the truth of certain propositions is beyond doubt: that the documents about Napoleon are not forged, that the apparatus really exists and so on. Wittgenstein (1969: § 88) contrasts such propositions with "the route travelled by inquiry"; the route of inquiry is so structured as to exempt certain propositions from doubt. If they are ever even explicitly formulated, such propositions 'lie apart' from the route of inquiry; they are "the places inquiry does not go" (Wittgenstein 1969: §88; Goodman 2002: 21). Such propositions are, for Wittgenstein (1969: §§ 342, 613) "in deed not doubted," since a doubt about such propositions, off the route of inquiry, would have the unwelcome consequence of "drag [ging] everything with it and plung[ing] it into chaos." Finally, Wittgenstein (1969: §§ 475, 359) describes our commitment to such propositions as "primitive" and "something animal." Unlike our commitment to propositions on the route of inquiry, the truth of which is believed on the basis of our commitment to these indubitable propositions, our commitment to a proposition of this latter kind does not reflect a belief but rather "a way of acting" (Wittgenstein 1969: § 110).

Propositions of this kind are known as 'hinge propositions' after a metaphor Wittgenstein uses to illustrate their nature. Wittgenstein (1969: § 341) writes,

the questions that we raise and our doubts depend on the fact that some propositions

are exempt from doubt, are as it were like hinges on which those turn.

5 As he goes on to explain a little later, "[w]e just can't investigate everything and for that reason we are forced to rest content with assumption. If I want the door to turn, the hinges must stay put" (Wittgenstein 1969: § 343).

6 It seems intuitively clear that hinge propositions are subject to an attitude of certainty and, indeed, there is plenty of evidence in Wittgenstein's text to support this view. But Pritchard's work makes clear that the certainty with which we are typically committed to hinge propositions is quite different from the certainty at which traditional epistemology aims, the special kind of knowledge sought by Descartes and his successors.

7 Pritchard (2012) provides an argument to support the idea that it is just the certainty with which we are committed to hinge propositions that is the obstacle to viewing those commitments as matters of belief or knowledge. As he points out, for something to be a ground for doubt, it has to be more certain than the target proposition which one is calling into doubt. If it were not more certain than the target proposition, Pritchard suggests, one would have a better basis for rejecting the ground for doubt than for rejecting the belief which is the target of the doubt itself. As he observes, this connects with Wittgenstein's (1969: §125) question, “What is to be tested by what?" Let us take the proposition, in normal circumstances, that one has two hands as an example of a proposition of which we are as certain as we are of any proposition. A doubt about the proposition that I have two hands would "drag everything with it and plunge it into chaos" for, in that case, it would not make sense to check my belief that I have two hands by looking for them, “[f]or why shouldn't I test my eyes by looking to find out whether I see my two hands?" (Wittgenstein 1969: § 125). It follows that I must be more certain of 
some other proposition (one functioning as a hinge proposition) than one that I call into doubt. Wittgenstein seems to want to treat the proposition that I have two hands, in normal circumstances, as just such a hinge proposition. Pritchard draws the conclusion that hinge propositions are "logically immune to a rationally irresistible doubt since by definition any ground for doubt in these propositions would be itself more dubitable than the target proposition itself" (Pritchard 2012: 256). There can therefore be no rational requirement to doubt a hinge proposition. Pritchard observes that this point about doubt applies, in equal measure, to its counterpart, belief. He writes,

just as grounds for doubt need to be more certain than the target belief that is doubted, so grounds for belief need to be more certain than the target proposition which is believed otherwise they can't be coherently thought to be playing the required supporting role. A direct consequence of this point is that just as there can be no rational requirement to doubt that which one is most certain of, so one cannot rationally believe it either. (Pritchard 2012: 257)

8 Contra G.E. Moore, then, the certainty with which one is committed to the proposition, for example, that one has two hands is not an indication that one believes or has knowledge of that proposition. As Pritchard argues elsewhere, this certainty is, for Wittgenstein, just what prevents the Moorean claim that one knows (or, a leviori, believes) these propositions:

Wittgenstein's claim is that whatever would count as a reason in favour of a claim to know must be more certain than the proposition claimed as known, since otherwise it would not be able to play this supporting role. But if the proposition claimed as known is something which one is most certain of, then it follows that there can be no more certain proposition which could be offered in its favour and stand as the required supporting reason. (2011: 525, cf. Wittgenstein 1969: § 243)

Pritchard examines, and finds wanting, various recent readings of Wittgenstein which attempt to defend the possibility of belief in, or knowledge of, hinge propositions. He puts forward the alternative suggestion that hinge commitments do not put us in the market for knowledge, are not beliefs (which could be acquired by the process of competent deduction, for example) and, while they may be treated as propositional attitudes, they cannot be treated as the specific propositional attitude of belief. While he admits that agents can recognise the logical relationships between non-hinge propositions and hinge propositions, Pritchard disputes that recognition of those relationships can be "part of a process through which one acquires belief, and thus rational belief, in these hinge propositions" (Pritchard 2012: 270). It follows that it is in the very nature of rational support that it is essentially local, a fact which Pritchard thinks is disguised by our ordinary epistemic practices in which doubts about hinge propositions do not, as a matter of fact, typically arise. The conclusion of Pritchard's argument is that the propositions of which we are most certain are not, even potentially, rationally supported but are rather the 'hinges' 'relative to which we rationally evaluate - and thus 'test' - other propositions" (Pritchard 2012: 257). The essentially local nature of rational support and the consequent rational groundlessness of our hinge commitments ${ }^{2}$ implied by this nonepistemic reading is what Pritchard takes Wittgenstein (1969: § 166) to be referring to when he writes of the 'groundlessness of our believing.'

Pritchard draws from Wittgenstein's 'hinge' metaphor for these certainties the thought that the rational groundlessness which they imply is not an optional or accidental feature of our epistemic practices but is, rather, "essential to any belief-system." ${ }^{3}$ But, in my view, the hinge metaphor also indicates an altogether more pragmatist import of this 
Wittgensteinian line of thought, captured by Wittgenstein's (1969: § 343) phrase "If I want the door to turn, the hinges must stay put." In my view, this phrase, "If I want the door to turn...," implies the relativity of our exemption from doubt of certain propositions to our practical interests, the dependence of that exemption on the fact that, at any given time, we are trying to get things done. And another of Wittgenstein's (1969: §§ 94-8) metaphors, contrasting the river bed with the flux of the river itself, takes this line of thought further. Wittgenstein $(1969$ : $\S \S 94,105)$ thinks of our picture of the world (to which the set of our hinge commitments is clearly integral) as the background to all our doubts, beliefs and inquiries: not itself a true or false proposition but the background against which true and false are distinguished; not itself an argument but the "element in which arguments have their life." This certain, indubitable background is compared to the bedrock of a river, the river itself being the flux of our dubitable beliefs, constantly open to question in the light of our hinge commitments. But, in metaphorical terms, parts of the bedrock may break off and become part of the flux of the river, while parts of the river itself may harden and become bedrock. The same shifting relationship obtains between our ordinary beliefs and the hinge commitments which form the background against which those beliefs make sense; although there must be a distinction, at any given time, between what is open to doubt and what is beyond doubt, that distinction is not, and cannot be a sharp or permanent one. The course of our experience, and our 'ways of acting' in relation to it, may cause us to re-evaluate things and to doubt what was once part of the indubitable background or it may lead us to take for granted something that was previously open to question. To my mind, the river metaphor carries the important implication that what counts as a hinge proposition at one time, in one context, may not count as a hinge proposition in a different context. The river metaphor seems to indicate not only that, for Wittgenstein, the fact that we exempt certain propositions from doubt is dependent on the fact that we have practical interests but also that the set of specific propositions that are exempted from doubt at any given time is relative to the specific practical interests we have at that time. To take an illustration from Wittgenstein (1969: $\S 421$ ) mentioned by Goodman (2002: 24), the proposition that I am in England could be 'on the route of inquiry' at one time, for example, if I am lost near the border between England and Scotland. At another time, however, it might express a hinge commitment which I take for granted when, for instance, I doubt whether next Monday is a national holiday. The shifting nature of what counts as a hinge commitment constitutes evidence for the relativity of hinge commitments, and therefore of the certainty with which we are necessarily committed to them, to our practical concerns. This relativity is connected, I think, with the Wittgensteinian rejection of the idea that hinge propositions, and the certainty with which we are committed to them, have to do with belief and knowledge.

11 It is in this sense, I suggest, that the Wittgensteinian conception of certainty may reasonably be described as a 'pragmatist' one. It embodies what Cornel West (1989: 89 et passim) has referred to as the specifically pragmatist hallmark of 'anti-epistemology' or the 'evasion' of philosophy centred around epistemology, as traditionally understood. In the next part of this paper, I want further to defend this view by considering the affinity between the Wittgensteinian conception of certainty just set out and the one in play in the work of the neglected thinker, broadly included among the pragmatists, George Santayana. 
Santayana develops his concept of 'animal faith,' which I want to read as a pragmatist concept of certainty, as a direct response to the Cartesian problem of scepticism. He criticises the Cartesian quest for knowledge based upon foundations of absolute certainty, ${ }^{5}$ arguing that there can be no such foundations and therefore, on this conception, no knowledge. Santayana offers his concept of animal faith as a more satisfactory idea on which to base an account of knowledge.

13 Santayana's (1923: 14ff., cf. Sprigge 1995: 34-5) argument is that solipsism is a no less coherent response to Cartesian-style scepticism than the more popular insistence on the existence of the external world. And he argues that, to be consistent, the sceptic is compelled to subscribe to an even more radical solipsism, what he calls 'solipsism of the present moment.' That experience exists is indubitable for the sceptic, as Descartes recognised, but a sense of identity and of a temporal order of experiences is only possible if it is assumed that the experiences are those of a being not simply composed of experiences. But this is one of the very points in question and the sceptic has no grounds for the assumption. As Santayana (1923: 28-9) explains, the solipsist might experience qualities which those committed to the existence of the external world would call 'pastness' or 'futurity' but without having any commitment to the existence of a real succession of events. Whether or not it is actually possible to live in this kind of state, it is the only theoretical position which involves no element of faith or belief that is not either itself certain or founded upon a certainty construed as a form of knowledge. Timothy Sprigge (1995: 38ff.) takes up Santayana's argument for the view that, if we confine ourselves to the goal of certainty in the knowledge sense, we will have no reason to believe in change since the experience of apparent change is perfectly compatible with fundamental doubt about the existence of real change. Someone might object that the solipsist accepts the existence of an experiential flux and that this flux just consists in experiences really giving way to one another, therefore even the solipsist should conclude that change really occurs: the flux of experience just consists in things which are in real, and not just specious, temporal relations to one another. But, in defence of Santayana, Sprigge (1995: 37) counters this objection by asking us to think of the experience of a swinging pendulum - which is the single experience of the pendulum in action. For real change to be experienced, this experience would have to give way to another experience. But this kind of change cannot be experienced in the same sense as the experience of the pendulum, which could be specious. Whereas it is possible to have an experience of the swinging pendulum without believing in the existence of anything other than that experience, it is not similarly possible to experience real change without being committed to some larger context, other than experience, within which the change occurs from one experience to another. In the experience of real change, a second experience would take over the story told by the first. And if this really happens they cannot just be aspects of a larger experiential content, existing only in the present, as the solipsist of the present moment would be forced to suggest. In other words, the solipsist of the present moment could not possibly believe in real change and is not compelled to believe in anything external to experience itself as it appears to her in the present moment.

14 So on the conception of knowledge aimed at by the Cartesian practitioners of the quest for certainty in the knowledge sense, there can be none. But, as Sprigge (1995: 47) summarises, "On the whole Santayana's explorations of scepticism are designed to show the hopelessness of a certain ideal of knowledge, that for which knowledge must be based 
on indubitable foundations, not to show the impossibility of knowledge on a more sensible interpretation of the term." That more sensible interpretation is referred to by Santayana as 'animal faith': human beings are compared to animals who have to cope with a difficult environment, their survival depending on a kind of implicit responsiveness to that environment of which belief in that environment's existence is not much more than a self-conscious expression (Sprigge 1995: 48). There may be no rational grounds for this belief but it is psychologically irresistible and practically indispensable. The phenomenon of shock is Santayana's (1923: 139ff.) specific example which he refers to as "the great argument for existence of material things" which "establishes realism" (Santayana 1923: 145, 142). He responds to the solipsist, understood as the connoisseur of the character of experience, in the following way: "But when a clap of thunder deafens me, or a flash of lightning at once dazzles and blinds me, the fact that something has happened is far more obvious to me than what it is that has just occurred" (Santayana 1923: 140).

The commitment to the existence of the external world, as Santayana describes it here, as a prime example of animal faith, is functioning in precisely the same way as a Wittgensteinian hinge commitment. It is an indubitable, 'animal' commitment, not itself subject to inquiry, which is taken for granted when anything is believed or doubted: the belief that the noise was a clap of thunder, for instance. In harmony with Pritchard's reading of Wittgenstein, it is taken to be rationally groundless. This commitment is what, for Santayana, forms the background to our ordinary everyday beliefs and doubts; in Wittgenstein's terminology, it is embodied in the groundless 'way of acting' which rationally grounds those beliefs. That this is so can be seen by one of Santayana's descriptions of animal faith as it is operative in everyday life, the way it functions in relation to the bread I am eating:

The bread, for animal faith, is this thing I am eating, and causing it to disappear to my substantial advantage [...]; [...] bread is this substance I can eat and turn into my own substance; in seizing and biting it I determine its identity and its place in nature, and in transforming it I prove its existence. (Santayana 1923: 83)

As Sprigge (1995: 63) summarises Santayana's general epistemology, it consists in "the recommendation to develop our view of the world on the basis, not of some supposed elementary data of consciousness, but of everyday beliefs which it is dishonest to pretend we do not hold." And it is this kind of epistemology, which Cornel West refers to as an anti-epistemology or an evasion of epistemology traditionally construed, that was further developed by the classical pragmatists like James and Dewey and their neo-pragmatist successors. West says of Dewey that he wilfully commits 'intellectual regicide': "he wanted," West writes, "to behead modern philosophy by dethroning epistemology" (West 1989: 89). Pragmatism can be understood as being motivated by a desire to evade epistemology as it has evolved under Descartes's shadow, inseparable from the quest for certainty in the knowledge sense. For Santayana, the scepticism which Descartes strategically embraced - in order eventually to replace it with certainty in the knowledge sense - is irrefutable and leads us into a hopeless solipsism of the present moment in which it is very likely impossible to live. And if we take certainty as our ideal of knowledge, we will soon find that there can be none: a consistent theoretical position, perhaps, but practically pointless and inconsistent with our everyday assumptions. So the pragmatist focus on, and understanding of, lived experience involves a very different concept of certainty and builds in the interaction between self and world which is questioned by the radical sceptic (Goodman 2002: 23). Experience does not yield the kind 
of certain knowledge which Descartes sought but rather commitments that, while rationally groundless, are practically indubitable and indispensable to us. And our commitment to propositions of this kind, which Santayana saw as the self-conscious expressions of 'animal faith' is ineluctably dubitable and uncertain if certainty is taken to be a kind of rationally supported belief or knowledge. To carry on the metaphor of faith: these commitments are like the tenets of a religion as it is lived and practiced, with all the attendant doubts, rather than as formalised in dry definitions and dogmas designed to exclude ambiguity and uncertainty.

17 I suggest, with Wittgenstein and Santayana, that the sense in which we take such nonoptional, yet rationally groundless commitments as certainties can have nothing to do with certainty in the knowledge sense. I have been arguing, on the contrary, that reflection on the nature of these commitments points to what I call a 'pragmatist' concept of certainty, found to be operative in the work of both Wittgenstein and Santayana. For both thinkers, propositions which express certainty do not express beliefs or knowledge but rather express the arational, 'animal' commitments which, as Pritchard (2012) shows, nonetheless ground all (essentially local) rational justification, functioning as the 'hinges' relative to which we test and evaluate other propositions and which are presupposed by these epistemic practices of testing and evaluation. philosophy exactly where I stand in daily life [..] and admit the same encircling ignorance." As regards the first principles, the discovery of which motivated Descartes, he says, "[t]hey can never be discovered, if discovered at all, until they have been taken for granted, and employed in the very investigation which reveals them" (Santayana 1923: 2). His account of animal faith, with its pragmatist conception of certainty, is offered, then, as the more congenial alternative to an irrefutable scepticism whose consequences are practically intolerable. Wittgenstein (1969: §§359, 475), in an apparently similar move, criticises the thought that reasons come to an end with special, foundational reasons and suggests instead that "when we reach bedrock we discover only a rationally groundless 'animal' commitment [...], a kind of 'primitive' trust" (Pritchard 2012: 259). Are Wittgenstein and Santayana offering the same kind of response to the problem of scepticism?

20 In my view, there are reasons to think that they are not. Santayana's response to scepticism is not a reductio ad absurdum. He does not attempt to show, or succeed in showing, that scepticism is incoherent or entails something incoherent. He admits that it entails a position (solipsism of the present moment) that is so far from being selfcontradictory that "it might, under other circumstances, be the normal and invincible attitude of the spirit" (Santayana 1923: 17). The difficulty he finds in maintaining such a position is the fact that it is signally unsuited to the "social and laborious character of human life" as a opposed, for example, to the life of a "creature whose whole existence 
was passed under a hard shell" which "might find nothing paradoxical or acrobatic in solipsism" and "might have a clearer mind"; such a creature "would not be troubled by doubts, because he would believe nothing" (Santayana 1923: 17). Santayana's response to scepticism, then, is an appeal to the impracticality of the position it entails. His response to scepticism is to accept the possibility of its truth while refusing to accept its truth on account of the unwelcome and impractical implications. The implications would perhaps not be so unwelcome for a creature under a shell who would doubt nothing because he believed nothing. But we human beings would be compelled to doubt everything that we believed and, on account of the 'social and laborious' character of our lives, could not live in such a state. It is partly for this reason that he professes to "stand in philosophy exactly where I stand in daily life": he views the local project of doubting everyday beliefs as analogous to the global sceptical project of doubting everything. For Santayana the sceptical project of applying doubt universally, although impractical, is perfectly coherent.

Wittgenstein, by contrast, wants to distinguish the sceptical practice of universal doubt from ordinary epistemic practices, including doubting. In Pritchard's (2011a: 524) view, Wittgenstein's implicit claim is that "the philosophical picture that the sceptic uses is completely divorced from the non-philosophical picture that we ordinarily employ." In ordinary life, our claims to know are connected with the practice of resolving doubts. For a doubt to be resolved, as mentioned earlier, the reason in support of the relevant belief has to be more certain than the belief itself in order to play the required supporting role. This Wittgensteinian picture of the structure of reasons operative in everyday life also applies to doubt:

a reason needs to be offered to motivate the doubt and, crucially, such a reason must be more certain that what is doubted since otherwise one would have more reason to doubt the reason for doubt that to doubt what is doubted. (Pritchard 2011: 527)

As Pritchard points out, this is the point of Wittgenstein's (1969: §553) claim that if, in the absence of a reason to doubt it, I need to check by looking whether I have two hands, I might as well doubt my eyesight as well. In other words, doubt, operative in our everyday epistemic practices, requires grounds that are more certain than the doubt itself, namely, hinge commitments which are "in deed not doubted." The sceptical project, on the other hand, denies such certainties: it demands that we doubt even what is most certain. But, if as Wittgestein thinks "there are hinges on which any epistemic evaluation must turn," this is an incoherent idea (Pritchard 2011: 530). ${ }^{6} \mathrm{~A}$ doubt applied universally, not constrained in the way that our ordinary epistemic practices are constrained, could have no supporting grounds, would be of no practical significance and, in Wittgenstein's (1969: $\S 450$ ) words, "would not be a doubt."

So unlike Santayana, Wittgenstein does not accept the coherence or legitimacy of the sceptical problem on account of the illegitimacy of its isolation and abstraction of the practice of doubting from its ordinary epistemic context, a context in which certainty, conceived in a pragmatist way, is operative in the form of hinge commitments. He accepts something of the spirit of scepticism in that hinge propositions, and the kind of certainty with which we are committed to them, point to 'the groundlessness of our believing.' But it is the very existence and necessity of hinge commitments that prevents Wittgenstein from accepting the sceptical idea that doubt can legitimately be applied universally and without restriction, even to what we take to be most certain. It is perhaps significant that, 
in the very paragraph where Wittgenstein (1969: § 359) echoes Santayana's epithet and describes certainty as 'something animal,' he goes on to explain it, in contrast to him, as "something that lies beyond being justified or unjustified." Whereas Santayana shares Wittgenstein's pragmatist conception of certainty, this is because, like the sceptic, he regards our certainties to be unjustifiable rather than moving beyond the distinction between being justified or unjustified as Wittgenstein attempts to do.

So although Wittgenstein and Santayana share a pragmatist conception of certainty, this concept constitutes a very different kind of response, for each thinker, to the problem of scepticism. For Santayana, it is a way of avoiding a very real and threatening problem; for Wittgenstein it is a means of exposing it as a pseudo-problem. Santayana's response to scepticism is a pragmatic one whereas Wittgenstein's is a logical one. I explore, in the concluding section, the broader implications of this difference between Wittgenstein's and Santayana's use of the pragmatist conception of certainty as a response to scepticism.

It might be thought, firstly, that Wittgenstein's logical response pre-empts Santayana's pragmatic one and that Wittgenstein's use of the pragmatist conception of certainty to expose the problem of scepticism as a pseudo-problem closes off the route to pragmatism, as further developed by philosophers like James and Dewey. This thought is expressed in Bertrand Russell's statement that the "scepticism embodied in Pragmatism is that which says 'since all beliefs are absurd, we may as well believe what is most convenient" (Russell 1910: 98). Wittgenstein's logical response to scepticism denies the premise that all beliefs are absurd; his argument, as we have seen, is that it is in the nature of rationally grounded beliefs that they turn on 'hinges' for which it makes no sense to demand further rational justification.

Apart from the fact that Russell's second phrase ('we may as well believe what is most convenient') is a crude caricature of the pragmatist position, ${ }^{7}$ the main import of pragmatism (its focus on lived experience, on the practical context in which apprehension occurs and on the consequences of beliefs for specific problematic situations) is perfectly compatible with the Wittgensteinian picture (Dewey 1952: 571-2). If scepticism is indeed a pseudo-problem, it seems perfectly reasonable to focus, as the pragmatists do, on the consequences of beliefs rather than on their foundations or hinges. As Wittgenstein pointed out, moreover, these hinges are rarely explicitly formulated or questioned in real life - they are "in deed not doubted." Pragmatists like Dewey are concerned with human practices of inquiry (logic included) insofar as they ramify in this practical demesne of lived experience; as Dewey puts it, pragmatists are

concerned with truth and falsity as having existential application, and as something determined by means of inquiry into material existence. For in the latter case the question of truth or falsity is the very thing to be determined. (Dewey 1952: 573)

If Dewey's pragmatic emphasis is preferred, the Wittgensteinian response to scepticism will count as a welcome further warrant for the pragmatist focus on lived experience, albeit one provided by a thinker who did not claim to be a pragmatist but to be merely "trying to say something that sounds like pragmatism." If, on the other hand, Wittgenstein's logical emphasis is preferred, the only route to pragmatism that is closed off will be the one mapped out by Santayana: one whose point of departure is acceptance of the irrefutability, and potential truth, of scepticism, an admission which presupposes 
the coherence of the sceptical problem. Indeed, Wittgenstein's argument might give someone with a logical turn of mind a much better reason than Santayana provides to avoid scepticism and instead to make the move into pragmatism. If we are not content, in Jamesian style, to allow temperament to decide the philosophical issue, we shall have to look for other grounds on which to base our decision whether, given our reflections on certainty, to view pragmatism as a live philosophical option. My own view, to repeat, is that both the logical and the pragmatic perspectives potentially leave the route to pragmatism open. Since Wittgenstein's argument can be used to justify in logical terms the taking of a pragmatist route (given an appropriate attitude to scepticism as a pseudoproblem, an illusory threat illegitimately abstracted from ordinary epistemic practices), and since the pragmatist perspective cannot endorse a purely logical point of view with no necessary existential application, my own view is that such a pragmatist route is the one that should be taken in preference to the narrow kind of logical route taken by Russell. It is, I suspect, one that most of us, in our less explicitly philosophical moments, will find that we have already taken.

So the first implication of the difference between Wittgenstein and Santayana on the issue of scepticism is that the move into pragmatism can be supported by the recognition of the compatibility of an appropriate version of pragmatism with the Wittgensteinian picture. To take this point further, secondly, this move has humanist implications, apparently recognised by both philosophers. Despite their difference on the issue of scepticism, both Wittgenstein and Santayana preserve what Cavell (1979: 241) has called the 'moral' of scepticism. ${ }^{8}$ Both agree, though for different reasons, that our beliefs are ultimately groundless, that they are not based upon foundations of what we would ordinarily call 'knowledge,' still less 'certainty' in the knowledge sense. This recognition of the ultimate groundlessness of our beliefs is developed by the classical pragmatists in the form of humanism. William James (1907: 242) endorses F.C.S.Schiller's understanding of 'humanism' as "the doctrine that to an unascertainable extent our truths are man-made products," the humanistic principle being succinctly expressed as follows: "you can't weed out the human contribution" (James 1907: 254). It is our concrete human concerns that determine the kind of attention we pay to things. And the kind of attention we pay to things determines what we find - it determines what stands out as salient to us, what seems worth mentioning, and what fades into the background - and this will not necessarily be the same in every context because, in each context, our practical concerns may be different. In Wittgenstein's language, our practical interests determine what is the bedrock and what is the river. James (1907: 251) illustrates with a relatively simple example: "You can take a chess-board as black squares on a white ground, or as white squares on a black ground, and neither conception is a false one." It is clear that, for James (1907: 253), all perception is interpretation, all seeing is 'seeing-as'; which, if any, of our perceptions may be treated as the more true, he thinks, "depends all together on the human use of it." To be a humanist, for James (1907: 247), is to recognise that "We receive [...] the block of marble, but we carve the statue ourselves." Since, in his phrase, "[m]an engenders truths upon [reality]" (James 1907: 257, 260), it follows that although the finite experiences which make up our human world are dependent upon each other, 'lean' on each other, as it were, the whole of human experience, if it makes sense to speak of such a whole, itself "leans on nothing"; when it comes to human experience as a whole, James (1907: 260) writes: "Nothing outside of the flux secures the issue of it." 
In conclusion, then, it is clear that this pragmatist form of humanism (which correlates with existential forms championed by certain European philosophers of the twentieth century) is bolstered by Wittgenstein's argument for the groundlessness of our believing. Thus humanism, according to which it makes no sense to speak of the world apart from the various modes of human engagement with it, is a major consequence of the pragmatist conception of certainty which, I have argued, is shared by Wittgenstein and Santayana. That conception preserves, in an illuminating way, Cavell's 'moral' of scepticism: the realisation that our beliefs are ultimately groundless. And that moral finds most direct expression in the humanism involved in the Jamesean version of pragmatism just mentioned. What that pragmatist form of humanism reflects, I think, is what West calls 'anti-epistemology' or the 'evasion' of philosophy, epistemologically construed. The implication is not that we are unable to provide legitimate rational justification for our beliefs but that a philosophical search for rational justification of those beliefs as a whole, a whole which 'leans on nothing,' will inevitably be frustrated. Wittgenstein's arguments, and Pritchard's readings, articulate very clearly just why this is so. They provide good arguments for adopting the humanistic evasion of epistemology which is a hallmark of existential phenomenology as well as pragmatism. And this evasive kind of philosophy begins with Cavell's (1980: 145) observation, made in relation to Emerson's thought, that our relationship to the world's existence is "closer than the ideas of believing and knowing are made to convey." If Wittgenstein is right about the arationality of certainty, the great value of the philosophies of existential phenomenology and pragmatism lies in their joint recognition that the main task of philosophy is to articulate the nature, and the various modes, of that intimate relationship.

\section{BIBLIOGRAPHY}

CAVELL S., (1979), The Claim of Reason: Wittgenstein, Skepticism, Morality and Tragedy, New York, Oxford University Press.

CAVELl S., (1980), “An Emerson Mood,” in The Senses of Walden, Chicago, Chicago University Press, 1992.

DEWEY J., (1952), “Experience, Knowledge and Value: A Rejoinder,” in P. A. Schilpp (ed.), The Philosophy of John Dewey, New York, Tudor Publishing Company, 2nd ed.

Goodman R. B., (2002), Wittgenstein and William James, Cambridge, Cambridge University Press.

JAMES W., (1922), Pragmatism: A New Name for some Old Ways of Thinking, New York, Longmans, Green and Co [1907].

PRITCHARD D. H., (2011), “Wittgenstein on Scepticism," in Kuusela O. \& McGinn M. (eds.), The Oxford Handbook of Wittgenstein, Oxford, Oxford University Press.

PRITCHARD D. H., (2012), "Wittgenstein and the Groundlessness of Our Believing," Synthese 189.

RusSell B., (1952), "Dewey’s New Logic," in Schilpp P. A. (ed.), The Philosophy of John Dewey, New York, Tudor Publishing Company, 2nd ed. 
RUSSELl B., (2009), “Pragmatism,” in Philosophical Essays, Abingdon, Routledge Classics [1910].

SANTAYANA G., (1923), Scepticism and Animal Faith, New York, Charles Scribner's Sons.

SPRIGGE T. L. S., (1995), Santayana: An Examination of his Philosophy, London, Routledge.

WEST C., (1989), The American Evasion of Philosophy: A Genealogy of Pragmantism, Madison, WI, University of Wisconsin Press.

WitTGENSTEIN L., (1969), On Certainty, Oxford, Blackwell.

\section{NOTES}

1. I call it a 'Wittgensteinian' concept, mindful of the limitations, recognised by Pritchard 2011, of the extent to which arguments extracted from On Certainty can confidently be attributed to Wittgenstein. As Pritchard reminds us, the material in this book was not prepared or sanctioned for publication by Wittgenstein himself.

2. A 'hinge commitment' is just a commitment to a hinge proposition.

3. Wittgenstein (1969: § 317).

4. Italics mine.

5. I shall refer to this ultimate aim of the Cartesian project as 'certainty in the knowledge sense.'

6. Italics mine.

7. Russell 1910, cf. Dewey 1952.

8. I owe this reference to Cavell to a remark made by Duncan Pritchard at a meeting of the Edinburgh Epistemology Research Group in April 2012.

\section{ABSTRACTS}

The ways in which Wittgenstein was directly influenced by William James (by his early psychological work as well his later philosophy) have been thoroughly explored and charted by Russell B. Goodman. In particular, Goodman has drawn attention to the pragmatist resonances of the Wittgensteinian notion of hinge propositions as developed and articulated in the posthumously edited and published work, On Certainty. This paper attempts to extend Goodman's observation, moving beyond his focus on James (specifically, James's Pragmatism) as his pragmatist reference point. It aims to articulate the affinity between Wittgenstein's thought on the topic of certainty and that of the neglected pragmatist thinker, George Santayana.

The paper draws on Duncan Pritchard's recent reading of Wittgenstein's On Certainty in order to articulate the concept of certainty involved in the notion of hinge propositions. It identifies two important and related points of affinity between this Wittgensteinian line of thought on certainty and the line of thought on the same topic articulated in Santayana's Scepticism and Animal Faith. The paper argues, firstly, that, both lines of thought reflect a pragmatist concept of certainty, according to which our most fundamental certainties are not conceived as purely theoretical objects of belief or knowledge but rather as the arational presuppositions of beliefs and practical action. Secondly, it examines the way in which the pragmatist concept of certainty functions, for the two thinkers as a response to scepticism. It argues that although the two 
thinkers' responses are very different, they are mutually compatible and, together, point towards the possibility of a distinctively pragmatist response to scepticism which involves an antiepistemological model of the intimate relation of the human self to the world.

\section{AUTHOR}

\section{GUY BENNETT-HUNTER}

University of Edinburgh

guy.bennett-hunter[at]ed.ac.uk 